\title{
Impact of the Participation of China's Service Industry in the Global Value Chain on Employment
}

\author{
Yan-gang CHEN \\ Wuhan University of Technology, Wuhan, Hubei 430000
}

\begin{abstract}
Keywords: Service industry, Global value chain, Economic globalization, Labor employment, Economic development.
\end{abstract}

\begin{abstract}
According to China's macro service industry data, this paper estimates the extent of its sub sectors' participation in the global value chain. Based on this, a linear regression model is applied to make quantitative analysis of the impact of the change of industrial structure and global value chain on labor employment. The results show that: the service industry's participation in the global value chain has a significant positive impact on the labor employment, and the influence of different service industries on labor demand is also different. This paper analyzes the measurement results and some differences, and puts forward some suggestions that can help to stabilize the employment of China's service industry and improve the participation of the service industry in GVC.
\end{abstract}

\section{Introduction}

\section{Research Background}

With the rapid development of the service industry and the improvement of information technology, it has become increasingly popular for China's service industry to participate in the international division of labor, more and more products production process is divided into different tasks, and assigned to different countries according to the principle of comparative advantage, and then convergence between the tasks and activities is achieved through the international trade, making the global value chain become an important feature of the world economic development. In recent years, China's various industries are developing rapidly. According to the output value data of industries in different countries provided by TiVA (Trade in Value Added) database, the output value in manufacturing, industry or service industry in China has increased significantly in recent 20 years. Because the manufacturing has the largest proportion of industrial output in China, many scholars explore the impact of the division of labor between domestic and foreign value chains on economic development from the perspective of manufacturing. However, the development of tertiary service industry is very rapid nowadays, the annual GDP proportion of which rises steadily. According to the data of the National Bureau of Statistics, the proportion of the added value of service industry in GDP is on the rise. Since 1970s, there has been significant increase in the proportion of the added value of the tertiary industry in the GDP. After entering the 21 st Century, the development of service industry accelerated, and broke through $40 \%$ in 2001 , and increased to $48.2 \%$ in 2014 . It is predicted that by 2020 , the proportion of service industry will account for more than 55\% of GDP, forming a service oriented economic structure. As a result, the simple study of the impact of the manufacturing participating in the global value chain on labor employment has been difficult to meet the factors affecting the current labor employment.

Moreover, because the data of previous scholars are relatively outdated, the reference needs of the current world economic development can not be met. Therefore, it is necessary for this paper to study the impact of the service industry's participation in the global value chain on labor employment, so as to make up for the deficiencies and insufficiencies of the factors that affect the labor employment in China's GVC industry.

\section{Research Purpose and Significance}

The modern service industry is a key factor for optimizing the economic structure, promoting industrial upgrading and enhancing the consumption structure in modern new normal environment of economic development, and the global value chain is a vivid description of global transnational, cross 
regional and inter-enterprise network organization activities of connecting production and sales, use and recycling process for realization of the value of goods or services. As everyone knows, the reallocation of production factors in each department realizes industrial structure adjustment of society, and the upgrading of the industrial structure is conducive to the improvement of Chinese subindustry production efficiency, and makes the international competitiveness be strengthened, so as to improve the degree of participation of enterprises in the global value chain.

In today's context of mutual influence of global value chain, industrial structure and employment, the internal network transaction mode is perplexing, in this sense, it is very necessary to study the relationship between the service industry structure and the global value chain, and explore their influence on labor employment, so as to get a more scientific development strategy.

\section{Research Methods}

Since global value chain, service industry structure and employment are interrelated and influenced, a complex internal network is formed. It is difficult for this paper to get relatively effective data to measure employment. This paper makes a simple and effective empirical analysis after the establishment of a linear econometric model based on the data of the macro service industry. The innovations of this paper are as follows: firstly, in this paper, nearly 9 years (2007-2015) of the latest macro-level data of sub sectors of service industry from National Bureau of Statistics was collected, the global value chain participation degree was calculated, which was introduced into the model for quantitative analysis; secondly, this paper referred to global value chain index changes of Chinese sub sectors of service industry (Wang Houshuang 2015), combined with the analysis of measurement model, and found that the higher the degree of industry participation in the global value chain, the greater the demand for employment labor; thirdly, a linear regression analysis and estimation of the GVC value which is difficult to calculate (input-output of the intermediate products are unpublished in the database) was made in this paper; fourthly, the demand degree for labor in the process of participating in the global value chain of different types of industries was compared.

\section{Related Literature Review}

With the development of economic globalization, the international community has proposed the value added trade statistics method, in order to make the trade statistics accurately reflect the true status of trade and benefit of division of economic entities, Koopman et al (2010) decomposed a country's general exports into foreign value-added and domestic value-added direct exports, domestic valueadded is exported to a third country after processing by the direct importing country and returned to the home country after processing, and further put forward the method for calculating GVC forward and backward participation degree and position index; Wang et al (2016) divided the production activities of a country into domestic production, transnational primary and transnational multiple production, and established a series of state department level global value chain measurement index, and used these indexes to analyze the evolution of production patterns of 35 sectors in 40 countries for 17 years.

For the research of service industry, foreign scholars have discussed the international division of labor status of service industry from two perspectives of traditional international division of labor and global value chain division of labor. McKee (1988) pointed out from the perspective of traditional division of labor that the developed countries transferred the traditional industries to developing countries, focusing on the development of producer services with relatively high technical content, and the developing countries mainly developed traditional industry and labor intensive service industry, and drew the conclusion that the status of international division of labor in the service industry of developed countries is higher, and the status of international division of labor in the service industry of developing countries is low. The service global value chain theory of Jones and Kierzkowski (1990) holds that with the development of technology, service trade effectively reduces the production cost of the global service chain, promotes the decentralization and roundabout of transnational sectional production, helping improve the status of international division of labor of a country's service industry. The domestic scholars have also paid attention to the influence of the 
global value chain on Chinese service industry development, and generally believe that in the background of international Intra-product division of labor mode, the development of service industry in developing countries is locked in the low end of the global value chain (Gu Naihua, 2006), mainly engaging in labor intensive service production with low technology content (Zheng Chunxia, 2007; Zheng Kaijie, 2008); and the productive service industry that represents the advanced productive forces can not develop effectively ((Jiang Jing and Liu Zhibiao, 2010), restricting the further promotion of the international division of labor in the service industry of developing countries (Dai Xiang, 2015).

In summary, the existing literature mainly analyzes how the extent of an economy participates in GVC affects the international division of labor and its development, but few people combine the participation degree of an economy in the global value chain with the employment effect of participating in the GVC. Based on this, the author refers to the global value chain participation index (GVC_ Participation) proposed by Koopman et al and combines the domestic value added of domestic sub sectors of service industry to researched on the impact of service industry participation in global value chain on labor employment.

\section{Data, Variables, and Econometric Models}

\section{Construction of Econometric Model}

In order to study whether the industry participation in global value chain increases the industrial employment, this paper takes the employment variable la-bor of sub sectors of service industry as the explained variable and takes the industry degree of participation in global value chain as the main explanatory variable to establish the following linear econometric model.

$$
\operatorname{In}\left(\text { labor }_{i t}\right)=\mathrm{c}+\alpha \cdot \mathrm{GVC}_{\mathrm{it}}+\sum \beta \cdot \mathrm{CV}_{\mathrm{it}}+\varepsilon
$$

Where, i refers to the service industry, $\mathrm{J}$ refers to wages, $\mathrm{t}$ refers to the particular year; labor ${ }_{\text {it }}$ refers to the industry employment quantity; $\mathrm{GVC}_{\mathrm{it}}$ refers to the industry degree of participation in global value chain; $\mathrm{CV}_{\mathrm{it}}$ refers to the industry control variables set that impact service industry employment quantity, including foreign GDP dummy variable of 6 service industries (wholesale and retail (wr), hotel and catering ( $\mathrm{hb}$ ), financial intermediaries (fi), transport storage and postal communications (tp),leasing and business services(lb) and other services(os); $\varepsilon$ is an error term. In this model, value of which means that the higher the degree of the participation of a service industry in the global value chain, the more the labor force employment. On the contrary, it the lower of the participation corresponds to the less labor force employment.

\section{Data Specification}

The data used in this paper are mainly derived from the following databases: the net investment of the National Bureau of Statistics and the tertiary industry employment statistics data. The data period is $2007-2015$,

Employment in the Service Industry labor $_{i t}$. Based on the data statistics of related employees in China's service industry, this paper selects and statistics the number of related industries based on the domestic service industry's participation in foreign trade. These industries include wholesale and retail, hotel and catering, financial intermediaries, transport and storage, postal services, leasing and business services, and other services. The total number of employment in these industries is counted and summarized in this paper.

Table 1. Total number of employment in the service industry

\begin{tabular}{llllll}
\hline Year & 2007 & 2008 & 2009 & 2010 & 2011 \\
\hline Number of employment (ten thousand) & 24404 & 25087.2 & 25857.3 & 26332.3 & 27282 \\
\hline Year & 2012 & 2013 & 2014 & 2015 & \\
\hline Number of employment (ten thousand) & 27690 & 29636 & 31364 & 32839 & \\
\hline Data source: National Bureau of Statistics of China & & & &
\end{tabular}


GVC the Measurement of the Global Value Chain. Upward (2013) combines the database of Chinese industrial enterprises and the Customs Trade database, and uses the KWW method to calculate the domestic value-added rate of Chinese enterprises. Kee and Tang (2016) and Zhang Jie (2013) are fully aware of the problems of indirect trade between enterprises and the identification of imported intermediate products. In this paper, the author uses the methods of understanding industry or enterprise participation in global value chain, and calculates the participation degree of service industry in global value chain from the macro level. The index of global value chain participation is measured by the rate of added value of foreign countries. Koopman. R., W. Powers, Z. Wang and S. J. Wei construct two indicators of "GVC_Position" and "GVC_Participation" to measure the status of a country in the global value chain labor division. Specifically, the following formulas are used to calculate the participation of the global value chain.

$$
\begin{gathered}
\text { GVC_Position }=\ln \left(1+\frac{I V_{i}}{E_{i}}\right)-\ln \left(1+\frac{F V_{i}}{E_{i}}\right) \\
\text { GVC_Participation }=\frac{I V_{i}}{E_{i}}+\frac{F V_{i}}{E_{i}}
\end{gathered}
$$

GVG_Position refers to the position of a country's i industry in the global value chain division. $I V_{i}$ refers to the indirect added value exports of a country's i industry, that is, the trade volume of intermediate goods exported to other countries by i industry in a country. $F V_{i}$ refers to the value of foreign import intermediates included in the export of the final products of the $i$ industry in a country. $E_{i}$ refers to the export volume calculated by value added of i industry in a country, the large index value represents that a country's certain industry is in the upstream of global value chain. The small value represents that a country's industry is in the downstream of the global value chain labor division. Considering that two countries may have the same GVC status index under the conditions of one industry has different degrees of participation in global value chain division of labor, so Koopman. R. et al. hold that the index of participation degree that represents the importance of a global industry chain to an industry in a country, namely GVC_Participation, should be combined with the index GVC_Position to examine the position of certain industry of a country in the global value chain. The greater the IV and FV value of an industry in a country, the higher the participation degree in GVC, and the higher the level of openness of the industry in the country.

Table 2. Participation degree index of China's service industry in GVC over the years

\begin{tabular}{llll}
\hline Year & GVC_Participation & Year & GVC_Participation \\
\hline 2007 & 0.5 & 2008 & 0.5 \\
2009 & 0.53 & 2010 & 0.51 \\
2011 & 0.55 & 2012 & $0.56^{*}$ \\
2013 & $0.6^{*}$ & 2014 & $0.64^{*}$ \\
2015 & $0.68^{*}$ & & \\
\hline
\end{tabular}

Data source: collected according to the TIVA data jointly published by WTO-OCED, in which the GVC data during 2012-2015 was estimated based on the previous year's linear regression since relevant data was not published.

http: //www.oecd-ilibrary. orb/

Gross Foreign Product of the Related Service Industries. Gross foreign product of related services industries is an important control variable that impacts the employment of service industry. Therefore, this paper summarizes the related data of gross foreign product of the following six major service industries from the website of the National Bureau of Statistics, collects and compiles nine consecutive years of data, the collection of gross foreign product constitutes the part of the service industry participating in the global value chain. 
Table 3. Gross foreign product of the sub sector of the service industry

\begin{tabular}{|c|c|c|c|c|c|c|c|c|c|}
\hline $\begin{array}{l}\text { Gross foreign } \\
\text { product } \\
(\$ 1000000)\end{array}$ & 2007 & 2008 & 2009 & 2010 & 2011 & 2012 & 2013 & 2014 & 2015 \\
\hline $\begin{array}{l}\text { Wholesale and } \\
\text { retail }\end{array}$ & 6604.2 & 6514.1 & 6135.8 & 6728.8 & 10324.1 & 13048.5 & 14646.8 & 18290.7 & 19217.9 \\
\hline $\begin{array}{l}\text { Hotel and } \\
\text { catering }\end{array}$ & 9.5 & 2950 & 7487 & 21820 & 11693 & 13663 & 8216 & 24474 & 72319 \\
\hline $\begin{array}{l}\text { Financial } \\
\text { intermediaries }\end{array}$ & 1667.8 & 14048 & 873374 & 862739 & 607050 & 10070.8 & 1510532 & 1591782 & 2424553 \\
\hline $\begin{array}{l}\text { Transport } \\
\text { storage and } \\
\text { postal } \\
\text { communications }\end{array}$ & 406548 & 2655.7 & 206752 & 565545 & 256392 & 298814 & 330723 & 417472 & 272682 \\
\hline $\begin{array}{l}\text { Leasing and } \\
\text { business } \\
\text { services }\end{array}$ & 560734 & 21717 & 20473.8 & 30280.7 & 25597.3 & 26740.8 & 27056.2 & 36830.6 & 36257.9 \\
\hline Other services & 855174 & 10943 & 19043.3 & 17300.8 & 29981.3 & 34818.6 & 47646 & 47661.3 & 62495.9 \\
\hline$\sum \beta \cdot \mathrm{CV}_{\mathrm{it}}$ & 26507 & 55907 & 56529 & 68811 & 74654 & 87804 & 107844 & 123120 & 145667 \\
\hline
\end{tabular}

\section{Data Summary}

The statistical results of the final data and the input of the data are as follows:

Table 4. Input data

\begin{tabular}{cccc}
\hline Year & $\begin{array}{l}\text { The number of employment } \\
\text { in the service industry }\end{array}$ & $\begin{array}{l}\text { GVC participation } \\
\text { degree index }\end{array}$ & Gross foreign product $(\$ 10000) \sum \beta \cdot \mathrm{CV}_{\mathrm{it}}$ \\
\hline 2007 & 24404 & 0.5 & 2650690 \\
2008 & 25087.2 & 0.5 & 5590717 \\
2009 & 25857.3 & 0.53 & 5652899 \\
2010 & 26332.3 & 0.51 & 6881131 \\
2011 & 27282 & 0.55 & 7465404 \\
2012 & 27690 & $0.56^{*}$ & 8780353 \\
2013 & 29636 & $0.6^{*}$ & 10784371 \\
2014 & 31364 & $0.64^{*}$ & 12311986 \\
2015 & 32839 & $0.68^{*}$ & 14566715 \\
\hline
\end{tabular}

Note: Logarithmic processing of each parameter during actual input

\section{Analysis of Measurement Results}

\section{Basic Results}

In the process of China's service industry participating in the division of labor in global value chain, it can reflect the structure of the industry's participation in the international division of labor through the part and proportion of various industries participating in the overseas value-added.

\begin{tabular}{crrrr}
\hline \hline Variable & Coefficient & Std. Error & t-Statistic & Prob. \\
\hline \hline C & 9.578127 & 0.102364 & 93.56886 & 0.0068 \\
GVC & 0.950962 & 0.223290 & 4.258862 & 0.1468 \\
I_WR & $-2.67 \mathrm{E}-09$ & $2.10 \mathrm{E}-08$ & -0.127000 & 0.9196 \\
I_HB & $-1.79 \mathrm{E}-07$ & $1.98 \mathrm{E}-07$ & -0.904383 & 0.5319 \\
I_FI & $1.99 \mathrm{E}-09$ & $6.85 \mathrm{E}-09$ & 0.291184 & 0.8196 \\
I_TP & $6.34 \mathrm{E}-08$ & $2.45 \mathrm{E}-08$ & 2.589941 & 0.2346 \\
I_OS & $1.81 \mathrm{E}-08$ & $4.35 \mathrm{E}-09$ & 4.160450 & 0.1502 \\
I_OS & $1.67 \mathrm{E}-08$ & $6.10 \mathrm{E}-09$ & 2.742601 & 0.2226 \\
\hline \hline R-squared & 0.999563 & Mean dependent var & 10.22932 \\
Adjusted R-squared & 0.996507 & S.D. dependent var & 0.101463 \\
S.E. of regression & 0.005997 & Akaike info criterion & -7.814719 \\
Sum squared resid & $3.60 \mathrm{E}-05$ & Schwarz criterion & -7.639408 \\
Log likelihood & 43.16624 & Hannan-Quinn criter. & -8.193039 \\
F-statistic & 327.0550 & Durbin-Watson stat & 3.084538 \\
Prob(F-statistic) & 0.042552 & & & \\
\hline \hline
\end{tabular}

Figure 1. The impact of six industries on GVC 
The econometric analysis of six industries in China's service industry shows that under this model, Prob (F-statistic) $<\alpha=0.05$, therefore, this paper rejects the original hypothesis and assumes that the model is significant. From a numerical point of view, the coefficient of GVC's participation is 0.95 , which indicates that under the significant conditions, the degree of the participation of the service industry in the global value chain is positively related to the labor employment of the service industry, that is, the greater the degree of industry participation in the global value chain, the more the number of employment in the service industry is.

Because sometimes the intermediate goods trade will lead to calculation repetition of trade statistical data, and domestic value added can reflect a country's participation in the GVC, the proportion of value added exports to the total value added of domestic exports can reflect the export structure of a country or region or the industry structure of GVC.

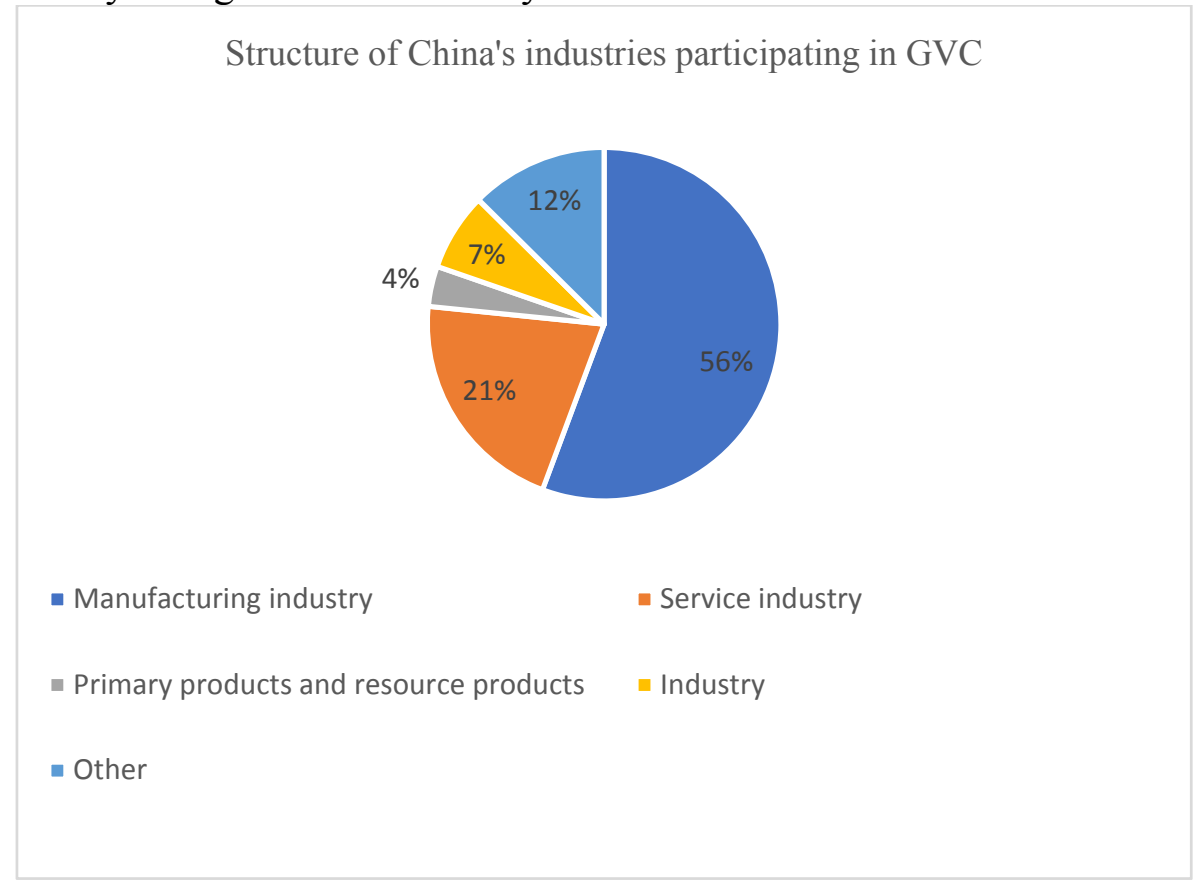

Data source: calculated and collected according to the world input-output table

Figure 2. Structure of China's industries participating in GVC

The figure represents the industry structure of China in GVC in 2014, it can be seen from the figure that, in the domestic added value of China's exports, the service industry is only second to the manufacturing industry and accounts for the proportion of $21 \%$, compared with the proportion of $16.38 \%$ previously calculated data in 2011 , China's service industry input has been increasing, with certain growth in domestic value added.

\section{The Impact of Participation of Sub Sector of Service Industry in GVC on Employment}

It can be seen from the results of the analysis that, under the conditions that other control variables stay unchanged, in the service industry, transport storage and postal communications have the greatest impact on the dependent variable labor $_{i t}$, namely service sector employment, and the transport storage and postal communications, leasing and business services and other service industries and the dependent variables are positively correlated; and wholesale and retail, hotel and catering the financial intermediary, and the dependent variables are negatively correlated with wholesale and retail having the largest negative effect. The reason is explored in this paper by studying on the industry demand for different skilled labor of each industry. It is understood in his paper that, in the process of participating in the global value chain of the service industry, the demand for labor in different industries is also different. Some of the labor demand is skilled labor intensive, while others are relatively unskilled labor intensive. For example, hotel, catering, wholesale and retail and other industries have higher demand for intensive labor, while financial intermediaries, transport storage and postal communications have higher demand for highly educated and highly skilled intensive labor. 
It is therefore necessary to examine whether the impact of enterprise's participation in global value chain on the various components of the labor market is different. The relevant scholars have made some research on this, and no longer will be described here. ( $<$ The Impact of Global Value Chain Participation on Labor Employment and Its Structure> Li Lei)

\section{Conclusion and Enlightenment}

The results show that the participation of the service industry in the global value chain can effectively increase the employment of the labor force. After joining the WTO in 2001, according to the relevant regulations, China has made concession commitments in terms of service trade. However, because many Chinese service industries are monopolized and lack market competitiveness, it is difficult to compete with foreign high-level service industries. Therefore, under the conditions of increasingly severe employment situation in China, effective measures to promote the participation of related industries in the global value chain can effectively alleviate the employment pressure faced by China.

Therefore, according to the conclusions of this paper, the following policy implications are concluded:

1. China should strengthen policy guidance, keep the core industrial chain and the industrial chain in favor of employment at home, so as to ensure the domestic content of the export value added. Many scholars believe that China's participation in the global value chain will be locked down at a low level because of its low labor quality and poor technology level, but this paper also needs to see that many industries are rising from the low end of value chain to the high-end. Especially with the speed of service industry's upgrading being faster, industries should be encouraged to rise to the high end of the value chain through innovation after entering the low end of the value chain.

2. Strengthen the training and improve the skill level of the labor force. The needs of different industries to labor intensive is not the same, nowadays, high-technology and knowledge-intensive practitioners are more welcomed by high-tech industries with fast development, in the process that enterprises are embedded in global value chain, the increased demand for high skilled labor may lead to wage inequality. Therefore, it is necessary to increase the labor skills training and improve the overall skill level of labor.

3. In order to make China's service industry progressively to the top of the global value chain, China still needed to strengthen core technology innovation. The government can formulate relevant policies and regulations to encourage basic science construction, guide the transformation of patent invention, and establish a scientific evaluation mechanism, so as to improve the Chinese position in the global value chain, and also improve the employment demand for high skilled labor. In the process of the gradual deepening of the economic integration in the world, such a policy is in line with the requirements of China's "the 13th Five-Years" planning.

\section{References}

[1] Flanagan, R., Khor, N. Trade and the Quality of Employment: Asian and Non-Asian Countries [Z] OECD, 2012.

[2] Breinlich, H., Criscuolo,C. international Trade in Services: A Portrait of Importers and Exporter [J].Journal of International Economics,2011,84(2):188-206.

[3] Wei Hao. Research on the Employment Effect of China's Textile Export: 1990-2007 [J]. Journal of International Trade, 2011 (1): 29-42

[4] Tian Wei and Yu Senjie, (2012) "Enterprise Productivity and Enterprise's 'Going Out' Outward Foreign Direct Investment: An Empirical Research Based on the Data at Enterprise Level," Economics (Quarterly) 2nd Issue, page 383-408.

[5] Xiao Ting. Study on the Change of Productivity, Property Right Structure and Wage Income in Sub Sector of Service Industry [J] 2015.10 
[6] Qiao Xiaoyong, Wang Geng, Zheng Chenxi. Research on the Status of China's Service Industry and its Subdivision Industries in the Global Value Chain *-- Based on the perspective of "StatusParticipation Degree - Dominant Comparative Advantage", [J] 2017.02.10

[7] Meng Dongmei, Zhao Xiaonan, Jiang Yanshu. The Reevaluation of the Competitiveness of China's Service Industry from the Perspective of Gobal Value Chain [J] 2017.02

[8] Li Lei, Sheng Bin, Liu Bin. The Impact of Global Value Chain Participation on Labor Employment and Its Structure [J] 2017.07

[9] Zhang Zhiming, Dai Peng, Cui Riming. Study on the Employment Effect of China's Value Added Export and its Influencing Factors [J]. Quantitative \& Technical Economics, 2016 (5): 103-121

[10] Li Qiang. Study on the Employment Effect of Enterprises Embedded in the Global Value Chain: Empirical Analysis of China [J] 2014.01 